\title{
RELEVANSI AJARAN MAHATMA GANDHI DENGAN KONSEP KEBEBASAN (STUDI KASUS HAK ASASI MANUSIA)
}

\author{
Martina Prativi \\ Prodi Seni Tari, Universitas Universal, Kompleks Maha Vihara Duta Maitreya \\ Bukit Beruntung, Sungai Panas, Batam, 29433 \\ E-mail : martina.prativi@uvers.ac.id
}

\begin{abstract}
ABSTRAK
Mahatma Gandhi menggulirkan konsep bermasyarakat yang lebih menekankan pada aspek-aspek kesetaraan manusia, sebagai kaum tertindas di india pada masa itu. Ahimsa, Nir-Kekerasan, satyagraha, hartal dan swadesi merupakan ajaran Gandhi yang bersifat merdeka untuk membebaskan masyarakat india dari penjajah. Paper ini mengambil studi pustaka dari tulisan - tulisan yang membahas ajaran Gandhi. Penulis menggunakan metode interpretasi dengan langkah sebagai berikut: inventaris data, klasifikasi data, deskriptif, analisis dan penarikan kesimpulan. Salah satu tujuan dari Paper ini adalah masyarakat membutuhkan perlindungan dalam melawan pemerintah yang semena - mena. Ajaran Gandhi telah membangun suatu pemikiran dengan paham kebebasan pada diri manusia terlebih dahulu dengan Ahimsa yaitu tanpa kekerasan. Melihat konsep kebebasan pada buku "jati diri Whitehead" dipaparkan bahwa kebebasan terdapat dua hal yaitu kebebasan negative dan kebebasan positif. Kebebasan positif adalah kebebasan yang terwujud pada diri manusia dalam mendapatkan haknya. Ahimsa sebagai inti dari ajaran gandhi mengajarkan rasa cinta damai dengan tanpa kekerasaan sebagai bentuk dari kebebasan positif.

Kata Kunci : Pemerintah, HAM, Kekerasan, Gandhi, Kebebasan
\end{abstract}

\section{PENDAhUluan}

Hak asasi Manusia adalah hak-hak yang telah dipunyai seseorang sejak manusia berada didalam kandungan. Hak Asasi Manusia (HAM) berlaku secara universal. Dasar-dasar HAM tertuang dalam deklarasi kemerdekaan Amerika Serikat (Declaration of Independence of USA) dan tercantum dalam UUD 1945 Republik Indonesia, seperti pada pasal 27 ayat 1, pasal 28 , pasal 29 ayat 2 , pasal 30 ayat 1 , dan pasal 31 ayat 1 . Kaitannya dengan itu, maka HAM yang kita kenal sekarang adalah sesuatu yang sangat berbeda dengan yang hak-hak yang sebelumnya termuat dalam Deklarasi Kemerdekaan Amerika atau Deklarasi Perancis. HAM yang dirujuk sekarang adalah seperangkat hak yang dikembangkan oleh PBB sejak berakhirnya perang dunia II yang tidak mengenal berbagai batasan-batasan kenegaraan. Sebagai konsekuensinya, negara-negara tidak bisa berkelit untuk tidak melindungi HAM yang bukan warga negaranya. Dengan kata lain, selama menyangkut persoalan HAM setiap negara tanpa kecuali, pada tataran tertentu memiliki tanggung jawab. Utamanya terkait pemenuhan HAM pribadi-pribadi yang ada di dalam jurisdiksinya termasuk orang asing sekalipun. Oleh karenanya, pada tataran tertentu menjadi sangat salah untuk mengidentikan atau menyamakan antara HAM dengan hak-hak yang dimiliki warga negara. HAM dimiliki oleh siapa saja, sepanjang bisa disebut sebagai manusia.

Setiap manusia selalu memiliki dua keinginan, yaitu keinginan berbuat baik, dan keinginan berbuat jahat.
Manusia berkeinginan berbuat jahat itulah yang menimbulkan dampak pada pelanggaran hak asasi manusia seperti membunuh, merampas, menjarah harta milik orang lain. Pelanggaran hak asasi manusia dapat terjadi dalam interaksi antara aparat pemerintah dengan masyarakat dan antar warga masyarakat. Namun, yang sering terjadi adalah antara aparat pemerintah dengan masyarakat. Kejadian ini sering timbul konflik dan ketegangan antar golongan pada komunitas tertentu di masyarakat.

Alasan di atas pula yang menyebabkan HAM bagian integral dari kajian dalam disiplin ilmu hukum internasional. Oleh karenannya bukan sesuatu yang kontroversial bila komunitas internasional memiliki kepedulian serius dan nyata terhadap isu HAM di tingkat domestik. Malahan, peran komunitas internasional sangat pokok dalam perlindungan HAM karena sifat dan watak HAM itu sendiri yang merupakan mekanisme pertahanan dan perlindungan individu terhadap kekuasaan negara yang sangat rentan untuk disalahgunakan, sebagaimana telah sering dibuktikan sejarah umat manusia sendiri.

Membicarakan manusia adalah sekaligus membicarakan kehidupan sosial yang berkaitan dengan komunitas. Manusia seutuhkan menurut Notoregoro adalah makhluk yang monopluraris dan berstruktur monodualis. Menyimpan segala potensi dan keunikan yang tak akan pernah selesai untuk dibahas dan dikaji. Komunitas yang memadai manusia seiring waktu berkembang sesuai dengan partisipasi manusia yang ada 
di dalam nya. Perkembangan ini pada akhirnya akan menuju pada kemanusiaan yang luhur yang dinyatakan oleh humanisme sebagai tujuan umat manusia.

Kehidupan berbangsa dan bernegara di Indonesia belakangan ini menunjukkan berbagai kekhawatiran. Bahaya laten yang dkhawatirkan adalah adanya konflik horizontal antar kelompok masyarakat, konflik berbau SARA hinggal konsentrasi perpolitikan yang tidak jelas. Jika ini dibiarkan akan memberikan penilaian negative, sebagai Negara yang mudah terpecah belah bagi bangsa Indonesia. Padahal kebudayaan Indonesia sebenarnya sangat mengangkat tinggi humanisme, praktek memanusiakan manusia secara layak.

Banyak tokoh filsafat yang menjadikan manusia sebagai objek kajiannya. Hal ini dikarenakan manusia adalah sumber dan objek persoalan sangat besar dan memang pantas dipersoalkan (Bagus, 2005). Namun, yang secara terang-terangan menyataan bahwa konsentrasi pemikirannya ditujukan pada humanisme adalah Muhamdas Karamcat Gandhi atau yang lebih dikenal dengan Mahatma Gandhi. Bahkan secra eksplisit Gandhi berujar, "My Nationalism is Humanistis, Nasionalisme saya adalah kemanusiaan" (Wisarja, 2007). Gandhi menggulirkan konsep bermasyarakat yang lebih menekankan pada aspek-aspek kesetaraan derajat manusia sebagai seorang pemikir dan pejuang selama hidupnya, Gandhi mengkampanyekan pentingnya atas imperialisme dengan nir kekerasan atau anti kekerasan. Model perlawanan yang ia gunakan adalah gerakan perlawanan yang tanpa kekerasan. Melalui gerakan ini diharapkan terbentuklah masyarakat anti kekerasan atau society non violence.

Meminjam termonologi Galtum, terjadi 4 macam krisis yang melanda dunia krisisi kekerasan, krisis penderitaan, krisis ancaman repesi dan krisis liingkungan hidup. Disini yang akan dibahas secara mendalam adalah berkaitan dengan krisis kekerasan, terlepas dari segala bentuk dan pengertian dari segala bentuk dan bentuk kekerasan itu sendiri (Wisarja, 2007). Maka, diperlukan suatu kajian yang membahas problem tersebut dengan mendalami konsep-konsep kemanusiaan yang membawa pengertian kebebasan.

\section{RUANG LINGKUP}

Dalam penelitian ini permasalahan mencakup:

1. Ajaran Mahatma Gandhi.

2. Relevansinya ajaran Mahatma Gandhi dengan Menegakan HAM.

3. Konsep kebebasan yang dibangun dalam ajaran Mahatma Gandhi.

\section{BAHAN DAN METODE}

Metode yang digunakan

1. Studi Pustaka

Penelitian ini merupakan jenis penelitian faktual mengenai tokoh, dimana yang menjadi objek materialnya adalah ajaran Gandhi yang ditinjau (objek formal) menurut kebebasan dalam filsafat manusia (Bakker dan
Charis Zubair, 2012). Sebagai penelitian faktual mengenai tokoh, maka penelitian ini lebih mengutamakan studi atas pustaka (referensi) yang berkaitan dengan tema penelitian.

2. Kajian Teori

Adapun teori yang digunakan adalah konsep kebebasan dalam jati diri Whitehead yang ditulis oleh Hardono hadi. Tahapan diawali dengan pengumpulan data yang digunakan dalam penelitian ini yakni data primer dalam buku "Jatidiri Manusia: Berdasar Filsafat Organisme Whitehead" dan sekunder sebagai sumber data. Analisis data menggunakan deskriptif kualitatif dengan menggabungkan ajaran Gandhi dengan Konsep Kebebasan. Terakhir adalah penarikan kesimpulan sebagai hasil akhir penelitian ini.

\section{PEMBAHASAAN}

Mohandas Karamachan Gandhi lahir tanggal 2 oktober 1869 di Porbandar, sebuah desa kecil di wilayah Gujarat. Ia adalah seorang anak perdana menteri di Desa tempat tinggalnya. Ibunya bernama Putlibai, seorang perempuan yang dalam banyak riwayat mengenai Gandhi diceritakan sebagai seorang yang lemah lembut dan merupakan sosok yang banyak menginspirasi.

Semasa Gandhi bersekolah di sekolah tingkat dasar, Gandhi bukan merupakan anak yang menonjol ataupun terlihat akan menjadi seorang tokoh yang terkenal. Namun, sejak kecil ia sudah menunjukan sikapnya yang berintegriti, salah satunya adalah beliau telah salah mengeja huruf. Ia menolak untuk meniru kawannya walaupun telah diberi peluang oleh gurunya. Gandhi telah menikah pada umur 13 tahun, hal ini diwajibkan karena adat orang india ketika itu mengharuskan untuk menikah muda. Beliau menikah dengan gadis yang sebaya denganya bernama Kasturbai.

Pada usia 18 tahun, beliau melanjutkan sekolahnya di Southampton, England dalam bidang undang undang. Di samping mempelajari undang - undang ketika dalam usia ini ia mulai menunjukan ketertarikannya dalam bidang keagamaan. Pelbagai kitab serta buku keagamaan dibacanya seperti hindu, Kristen, yahudi dan islam. Pada tahun 1891 ia lulus dan pulang ke India dan bekerja sebagai menjadi pengacara.

Ketika ke Afrika, untuk pertamakalinya Gandhi menghadapi tindakan diskriminasi yang pertama. Saat itu ia sedang dalam sebuah perjalanan naik kereta dan diusir oleh salah seorang penumpang berkulit putih yang ada disana warna kulitnya yang berbeda. Namun, pada saat itu Gandhi menolak dan akhirnya diusir keluar dari kereta tersebut. Pengalaman tersebut memberikan dampak yang luar biasa bagi Gandhi dan menjadikan seorang aktivis yang ingin memperjuangkan masalah diskriminasi.

Saat kembali ke India Gandhi menjadi sosok yang inspirasional karena kontribusinya dalam melawan penjajahan dari inggris dan membawa India keluar dan masa jajahan dengan ajaran - ajaranya yang sarat nilai 
kemanusiaan dan menolak kekerasan. Hingga pada tahun 30 Januari 1984. Ia meninggal karena dibunuh oleh seorang laki - laki yang marah kepada kepercayaan Gandhi yang menginginkan rakyat Hindu dan Muslim diberikan hak yang sama.

\subsection{Ajaran Mahatma Gandhi dalam Menegakan HAM}

Ajaran-ajaran yang ditekankan oleh Gandhi adalah ajaran mengenai anti kekeraaan, ahimsa secara harafiah artinya "tidak meyakiti" disini maksudnya adalah tidak hanya menyakiti secara fisik, tetapi juga tidak membenci maupun memperalat orang lain. Tidak menyakiti mempunyai arti yang luas. Ajarannya menekankan pada perjuangan kemerdekaan harkat hidup manusia dan pemberontakan tanpa menggunakan kekerasaan. Ajaran Gandhi yang pertama adalah ahimsa. Kata ahimsa berasal dari sunsekerta yang berarti tanpa kekerasaan. Maksudnya adalah kegiatan melawan atas ketidakadilan dengan tanpa kekerasaan atau tindakan damai. Dari eksperimen-eksperimen tersebut kemudian mengonsep beberapa kaidah tingkah laku yang sarat dengan nilainilai moral. Sebagai contoh, konsep sentral dalam pemikiran Gandhi yaitu ahimsa merupakan prinsip yang ditemukan dalam ajaran agama namun oleh Gandhi digunakan sebagai dasar dalam konsep-konsep sosial politiknya (Poerbasari, 2007).

Kontribusi terbesar kepada Gandhi kepada kemanusiaan adalah pesannya terhadap nir kekerasan sebagai jalan perdamaian, keadilan dan Tuhan. Gandhi sangat serius ketika menghayati perintah-perintah suci ajaran injil bahwa tidak boleh membunuh dan cintailah musuh-musuhmu. Dia memandang bahwa ajaran ini parallel dengan tradisi hindu tentang ahimsa (tidak boleh membunuh). Tetapi, Gandhi mempunyai pemikiran bahwa nir kekerasan bukannlah sekedar penolakan untuk membunuh. Nir kekerasan adalah sebuah aksi atau tindakan cinta kasih dan kebenaran sebagai kekuatan yang positif untuk mewujudkan perubahan sosial. Nir kekerasan akan selalu berhasil karena prinsip ini menggunakan metode kerelaan serta menanggungkan semua penderitaan dengan penuh rasa, cinta, dan meluluhkan hati umat manusia (Dear, 2007).

Ajaran lainnya adalah satyagraha. Secara harfial satyagraha berarti suatu pencarian kebenaran dengan tidak mengenal lelah. Bergantung teguh pada kebenaran artinya satyagraha merupakan jalan hidup seseorang yang berpegang teguh kepada Tuhan Yang Maha Esa dan mengabdikan seluruh hidupnya pada Tuhan Yang Maha Esa. Satyagraha adalah suatu pencarian kebenaran yang tidak mengenal lelah. Kata satya (kebenaran) diturunkan dari sat yang berarti "ada". Dalam realitas, tiada yang selain kebenaran.

Pengabdian terhadap kebenaran merupakan satusatunya justifikasi bagi keberadaan atau eksistensi kita. Semua aktivitas kita harus berpusat pada Kebenaran. Kebenaran harus berada dalam setiap hembusan nafas kehidupanmu. Manakala bangsa ini telah mencapai kemajuan spiritual dalam tingkatan ini, semua aturan kehidupan bisa ditegakkan dan kesetiaan serta kepatuhan terhadapnya kan lahir secara alamiah. Tetapi tanpa Kebenaran, suatu prinsip atau aturan kehidupan tak mungkin ditaati (Dear, 2007).

Makna dasar dari satyagraha adalah "berpegang pada kebenaran" sehingga melahirkan "kekuatan-kebenaran". Gandhi juga biasa menyebutnya dengan "kekuatan-cinta kasih" atau "kekuatan jiwa". Gandhi menerapkan satyagraha dalam tahapan paling awal, ia menyadari bahwa pencarian kebenaran tidak memperbolehkan penggunaan kekerasan terhadap musuh, justru harus menginsyafkan musuh dari kesalahannya. Hal ini harus dilakukan dengan kesabaran, simpati dan empati. Oleh karena apapun yang tampak benar dimata seseorang, bagi orang lainya biasa saja dianggap sebagai kesalahan. Kesabaranlah yang mesti dikedepankan sebagi salah satu alat pengorbanan dan pengendalian diri. Demikianlah, kita harus memaknai bahwa pembelaan dan mempertahankan. Kebenaran tidak boleh dilakukan dengan menimpakan penderitaan terhadap musuh, tetapi penderitaan dan pengorbanan itu harus ditanggung oleh dirinya sendiri (Dear, 2007).

Aktivis satyagraha (orang-orang yang berpegang teguh pada kebenaran) tidak memiliki prasangka buruk, tidak mendasarkan hidup mereka dalam kemarahan, tetapi tetap menolak tunduk kepada "musuh" mereka atau penindas karena aktivis satyagraha memiliki kekuatan dalam dirinya untuk menanggungkan segala penderitaan dan pengorbanan. Oleh karena itu, seorang aktivis satyagraha harus memiliki semangat keberanian serta memiliki sifat pemaaf dan melimpahkan kasih sayang kepada semuanya. Satyagraha adalah jalan nirkekerasan. Oleh karena itu, satyagraha memiliki dasar pembenaran, bahkan satyagraha adalah jalan benar, di setiap saat dan semua tempat.

Kekuatan bersenjata adalah kekerasan dan dikutuk oleh semua agama. Sebenarnya, orang-orang yang mendukung penggunaan senjata memiliki banyak keterbatasan. Baik keterbatasan jumlah maupun kekuatan dari senjata itu. Tetapi satyagraha tidak memiliki batas. Siapapun orangnya, tanpa kecuali, ketika dia memiliki kemapuan sebagai seorang aktifis satyagraha maka dia pasti sanggup dan rela berkorban menggungkan semua bentuk penderitaan. (Dear, 2007 : 147)

Ajaran Gandhi selanjutnya adalah swadesi atau cinta produk negeri sendiri. Pengertiannya adalah cinta tanah air sendiri, mendahulukan pengabdian terhadap negeri sendiri terlebih dahulu. Hal ini dimaksudkan oleh Gandhi agar rakyat india dapat hidup mandiri dan berdiri di atas kaki sendiri. India merupakan bangsa dengan jumlah penduduk terbesar kedua di dunia, sudah barang tentu sumber daya manusia juga melimpah. Baik dalam sisi industri atau manufaktur. India memiliki kekuatan yang memadai untuk mandiri.

Hartal adalah semacam pemogokan nasional, tokotoko dan urusan dagang ditutup sebagai protes politik, 
para pekerja melakukan pemogokan. Pertama kalinya Gandhi memutuskan untuk menentang pemerintahan kolonial Inggris di India, ia memutuskan melanggar dengan hartal. Ia mengatakannya suatu hari agar kegiatan dagang dihentikan, tokotoko ditutup, dan para pekerja/buruh mogok kerja. Hartal ini merupakan permulaan dari perjuangan selama 28 tahun, yang akhirnya dapat mengakhiri penjajahan Inggris atas bangsa India. Hartal dilakukan oleh rakyat India sebagai sebuah protes politik, namun hari-hari mogok itu dihabiskan dengan berpuasa dan kegiatan keagamaan lainnya (Nicholson, 1994).

Hartal sebagai protes politik. Hartal sendiri memiliki makna mogok. Sadar akan kekuatan buruh yang besar di India, Mahatma Gandhi menyerukan mogok kerja bagi buruh-buruh pabrik yang dimiliki inggris jika terjadi kesewenang-wenangan dari pihak majikan. Langkah ini dinilai Gandhi cukup efektif untuk memberikan jera bagi bangsa penjajah. Ketika para buruh mogok, maka produksi akan terhenti dan kerugian tertumpu pada pihak penguasa.

\subsection{Konsep Kebebasan Mahatma Gandhi}

Ajaran Gandhi tidak secara terus terang membicarakan kebebasan, tetapi dalam ajarannya Gandhi seakan membangun suatu kebebasan pada diri manusia. Berawal dari tindakan diskriminasi yang dialami Gandhi, munculah ide untuk membebaskan manusia dari tindakan-tindakan yang tak adil. Serta, Kebebasan dari kolonial inggris agar rakyat india tidak tertindas. Dalam ajaran Mahatma Gandhi Satyagraha dikatakan bahwa manusia dapat mencari kebenaran tanpa kenal lelah dan putus asa. Ini menjelaskan bahwa pada diri manusia terhadap tindakan untuk menentukan dirinya. Ajaran Satyagraha mengajarkan untuk membebaskan manusia dari sifat jahat. Membebaskan manusia dari prasangka buruk dan membangun rasa simpati ke sesama manusia. Satyagraha mengajarkan akan manusia menahan hawa nafsu. Menahan kemarahan yang akan membebaskan manusia dari penderitaan.

Bicara tentang Ahimsa adalah bicara tentang anti kekerasaan yang mana ini menjadi inti dari ajaran Gandhi. Ahimsa adalah larangan untuk saling menyakiti baik sesama manusia ataupun hewan. Menyakiti tidak hanya diartikan menyakiti secara fisik tetapi juga menyakiti dalam bentuk lain. Ahimsa adalah bentuk nirkekerasan atau anti kekerasan dimana manusia tidak boleh melawan kekerasaan dengan kekerasaan. Gandhi mengajarkan untuk melawan kekerasaan adalah dengan kesabaran dan tindakan- tindakan perdamaian yang membawa ke sebuah kesepakatan bersama. Ajaran ini menjadi perhatian karena membebaskan manusia dari sifat negatif. Paham ini sekaligus berdampak besar bagi rakyat india karena melawan pemerintah inggris tidak dengan perang tapi dengan perlawanan cinta damai. Ajaran ahimsa melahirkan ajaran yang salah satunya adalah hartal. Hartal merupakan ajaran yang sangat membuat rakyat india bersatu. Hartal adalah mogok masal yang dilakukan bersama-sama. Berkaitan dengan kebebasan maka letaknya ada pada kebebasan kaum buruh atas tindakan semena-mena yang dilakukan sang majikan. Tindakan mogok yang dilakukan oleh para buruh di india adalah untuk mendapatkan hak-hak mereka.

Sikap yang tepat untuk mengadakan komunikasi bagi Gandhi adalah dengan kasih atau ahimsa. Ahimsa merupakan sarana komunikasi antar peribadi, dan sungguh-sungguh dapat menghargai dan menjunjung tinggi kodrat dan harkat kemanusiaan orang lain. Melalui sikap yang demikian umat manusia bersama-sama dapat membina persatuan dan hidup bermasyarakat yang lebih manusiawi, damai dan diwarnai oleh rasa persaudaraan. Banyak pihak mengakui baik kawan maupun lawan, Gandhi dalam perjuangannya selalu mengkampanyekan pentingnya perlawanan atas imperialisme dengan nirkekerasan atau tanpa-kekerasan. Gandhi selalu mengedepankan kepentingan kemanusiaan secara lebih luas daripada melakukan perlawanan dengan jatuhnya korban-korban manusia. Perlawanan tanpa kekerasan ini menjadi model gerakan sekaligus pemikiran Gandhi dalam memperjuangkan ide-ide kemanusiaan (Wisarja, 2018).

Ajaran swadesi, Gandhi mencoba membebaskan rakyat india dari ketergantungan pihak inggris. Hal yang diajarkan dari Gandhi adalah rakyat india mulai membangun perekonomian sendiri dan membuat produksi-produksi dalam negeri yang berguna bagi rakyat. Ajaran ini berawal dari perhatian Gandhi terhadap produksi kapas yang sangat banyak di india. Gandhi mengisi kesehariannya dengan memintal kapas menjadi benang. Gandhi pernah mengatakan "Pakaianpun india harus bisa membuatnya sendiri tanpa di impor dari inggris". Adanya ajaran swadesi membuat india menjadi penghasil ekspor kain terbesar di dunia.

Dari keterangan diatas menunjukkan bahwa ajaran Gandhi memiliki konsep kebebasan dalam setiap ajarannya. Konsep yang ditawarkan adalah konsep kebebasan yang membebaskan manusia dari sifat buruk dan membebaskan manusia dari ketergantungan. Dilihat kebebasan yang lebih luas Gandhi dapat menciptakan kebebasan bagi rakyat india kala itu. Kebebasan dari pihak penjajah dan tindakan diskriminasi orang "kulit putih" terhadap "kulit berwarna" di afrika selatan. Pembelaan Gandhi dalam memperjuangkan Hak Asasi Manusia (HAM) di india dan Afrika Selatan menghasilkan suatu kebebasan pada diri manusia baik kebebasan hidup, bicara, dan beragama.

\subsection{Relevansi Kebebasan dalam "Jatidiri Whitehead"}

Kebebasan berkaitan dengan moral dan sosial dalam kehidupan manusia. Bicara kebebasan maka akan berkaitan dengan HAM. Melihat konsep kebebasan pada buku "jati diri Whitehead" dipaparkan bahwa kebebasan terdapat dua hal yaitu kebebasan negative dan kebebasan positif. Kedua kebebasan ini yang nanti akan membuat 
kebebasan lebih jelas dipahami. Kebebasan negative adalah tindakan kebebasan yang sebebas-bebasnya. Menurut hardono hadi (2000) kebebasan negatif berarti tidak adanya rintangan, campur tangan, paksaan atau kontrol ketat. Sedangkan kebebasan positive lebih menekankan kebebasan yang memiliki tujuan tertentu. Maksudnya adalah kebebasan pada diri manusia dimana dalam menentukan jalan hidupnya untuk meraih cita-cita yang diimpikan. Kebebasan ini lebih cenderung kearah kebebasan manusia untuk menentukan pilihannya sendiri.

Kebebasan diawali dengan adanya kehendak pada diri seseorang. Kehendak merupakan hal yang paling menentukan dalam perwujudan diri seseorang entah itu dalam tundakan, perasaan, atau pikiran. Kekuatan kehendak bisa menegaskan apa yang dirasa, dipikir dan dipertimbangkan. Tanpa kehendak yang kuat apapun yang dirasa dan dipikirkan tidah mendapat perwujudan yang selayaknya. Meskipun orang mempunyai perasaan yang halus dan pikiran yang tajam, tetapi kalau tidak disertai kehendak yang teguh tidaklah akan menghasilkan sesuatu. Perbedaan antara emas dan sampah terletak pada kualitasnya didalam bakaran api. Sampah mudah hangus sedangkan emas semakin menyala keasliannya. Demikian juga dengan kualitas kehendak (Hadi, 2000).

Kehendak sebagai perwujudan diri manusia. kehendak berada pada tindakan, perasaan atau pikiran manusia. Kehendak pada diri manusia memberikan kekuatan untuk sesorang meraih cita-cita. Kehendak dasar pada diri sesorang mengantarkan manusia untuk melakukan kebebasan positif bukan negatif. Kebebasan positif mewujudkan kepada manusia dalam menentukan pilihan. Agar melanjutkan ke tindakan atas dasar inisiatif pribadi dan membawa ke minat manusia ke dalam bentuk-bentuk kegiatan yang diekspresikan ke tindakan kebebasan.

\section{KESIMPULAN}

Kesimpulan dari penelitian diatas bahwa ajaran gandhi bermakna kebebasan. Makna kebebasan yang dapat dipahami adalah makna jiwa yang bebas pada ajaran ahimsa. Hartal sebuah kebebasan dari ketertindasan sebagai pekerja dan swadesi pembebasan secara ekonomi. Konsep kebebasan yang ditawarkan oleh Gandhi adalah terbebas dari sifat buruk dan membebaskan manusia dari ketergantungan. Kebebasan tersebut adalah menghilangkan ketergantungan pada orang lain ataupun ketergantungan pada pemerintah. Satyagraha merupakan kebebasan dari tindakan-tindakan dari ketidakadilan. Sebuah gerakan massal menuntut kebenaran serta hak manusia. Hak Setiap individu dimaknai oleh tidakan-tindakan yang tidak adil seperti ketertindasan dan pengekangan di masyarakat. Kebebasan berbicara, hidup dan beragama adalah perjuangan hak masyarakat pada diri manusia. Hak asasi manusia adalah perwujudan kehendak di dalam hati untuk bebas dari rasa tertekan, tertindas dan belenggu pada pikiran manusia. Kebebasan positif adalah kebebasan yang terwujud pada diri manusia dalam mendapatkan haknya. Ahimsa sebagai inti dari ajaran gandhi mengajarkan rasa cinta damai dengan tanpa kekerasaan sebagai bentuk dari kebebasan positif.

\section{SARAN}

Penelitian ini masih jauh dari kata kesempurnaan dan berharap penelitian ini sebagai awal untuk penelitian ajaran Mahatma Gandhi selanjutnya. Adapun kekurangan sebagai langkah awal untuk penelitian ini kedepannya. Saran penyusun bagi para peneliti yang tertarik terhadap permasalahan Hak Asasi Manusia (HAM) ataupun kebebasan manusia agar lebih melebarkan jangkauan pembahasan dan kajiannya, sehingga kesimpulan dari penelitian yang dilakukan akan lebih memadai dan lebih sempurna lagi.

\section{DAFTAR PUSTAKA}

Bagus, lorens. Kamus Filsafat. 2005. Jakarta: Gramedia Pustaka Utama

Bakker, A. dan A. Charis Zubair, 2012. Metodologi Penelitian Filsafat. Kanisius: Yogyakarta

Dear, John. 2007. Intisari Ajaran Mahatma Gandhi. Bandung : Nusamedia

Fischer, Louis. 1967. Gandhi : Penghidupannja dan Pesannja untuk Dunia. Jakarta : Gunung Sahari

Hadi, Hardono. 2000. Jatidiri Manusia: Berdasar Filsafat Organisme Whitehead. Yogyakarta : Kanisius

Mehta, Ved. 2011. Ajaran - Ajaran Mahatma Gandhi. Yogyakarta : Pustaka Pelajar

Nicholson, Michael, 1994. Mahatma Gandhi, Pahlawan yang Membebaskan India dan Memimpin Dunia dalam Perubahan Tanpa Kekerasan. terj. Hilman Farid Seiadi. Gramedia Pustaka Utama: Jakarta.

Poerbasari, Agnes. Sri. 2007. Nasionalisme humanistis Mahatma gandhi. Jurnal Vol 9 No.2, 185-186

Wisarja, I Ketut. 2007. Gandhi dan Masyarakat Tanpa kekerasan. Surabaya: Paramitha

Wisarja, I. K., \& Sudarsana, I, K. 2018. Membaca ulang pemikiran Mahatma Gandhi. Jurnal Vol 7 No.1, 1415 